\title{
Study on Species Diversity and Stand Structure in Meru Betiri National Park
}

\author{
Heru Dwi Riyanto and Agus Wuryanta \\ Balai Penelitian Teknologi Kehutanan Pengelolaan Daerah Aliran Sungai, \\ Jl. A.Yani, Pabelan P.O. BOX 295 Kartasura-Surakarta Telp.(0271)716709, Fax. (0271)716959 \\ Corresponding E-mail: rherudwi_61@yahoo.com
}

\begin{abstract}
National parks are forest ecosystems that contain biotic and abiotic resources. Biodiversity is the data and information necessary to understand the degree of loss of species diversity and formulate a sustainable alternative of decline in these resources. The research objective is to study the reciprocal relationship between elevation and habitat of a species in an ecosystem. Research conducted at the National Park (TN) Meru Betiri. The results show that there are spatial variabilities of the species diversity based on the elevation in the study area. Elevation is inversely proportional to species diversity index, the higher the elevation, the species diversity index tends to decline, but the index of the importance of endemic species have increased. Group stand structure and species composition is influenced by the level of elevation with their own environment.
\end{abstract}

Keywords: Meru Betiri National Park, species diversity, stand structure, species composition

\begin{abstract}
Abstrak
Taman Nasional adalah ekosistem hutan yang mengandung sumberdaya biotik dan abiotik. Keanekaragaman hayati adalah data dan informasi penting untuk memahami besarnya kehilangan keanekaragaman spesies dan merumuskan alternatif yang berkelanjutan dari penurunan sumber daya tersebut. Tujuan penelitian adalah untuk mempelajari hubungan timbal balik antara ketinggian tempat dengan hunian suatu spesies dalam suatu ekosistem. Penelitian dilaksanakan di Taman Nasional (TN) Meru Betiri. Hasil penelitian menunjukkan bahwa terdapat variabilitas spasial keanekaragaman hayati berdasarkan ketinggian tempat pada taman nasional tersebut. Elevasi atau ketinggian berbanding terbalik dengan indeks keanekaragaman spesies, semakin tinggi elevasi atau ketinggian maka indeks keanekaragaman spesies cenderung menurun, tetapi indeks nilai penting dari spesies endemik mengalami peningkatan. Kelompok struktur tegakan dan komposisi spesies dipengaruhi oleh tingkat elevasi dengan lingkungan mereka sendiri.
\end{abstract}

Kata kunci: Taman Nasional Meru Betiri, keragaman spesies, struktur tegakan, komposisi spesies

\section{Introduction}

Meru Betiri National Park is one of the tropical forest in Java island ( $8^{\circ} 20^{\prime} 48^{\prime \prime}-8^{0} 33^{\prime} 48^{\prime \prime} \mathrm{S}$ and $113^{\circ} 38^{\prime} 48^{\prime \prime}-113^{0} 58^{\prime} 30^{\prime \prime} \mathrm{E}$ ), and its status is for the conservation of fauna and floral species, and world heritage site and a biosphere reserve. The Park is situated within a predominantly rural farming community. Therefore, some areas were converted into farms, particularly for cash crop, several nontimber forest product which the people needed for some of their other economic activities are also depleted source. Along the change of period to governance in the new order becomes a reform governance makes the TN-MB ruined as the effect of foray. Watershed management office of Sampean-Madura DAS (2002) reported that National Park of Meru-Betiri which its width 58.000 $\mathrm{Ha}$, for about $4.023 \mathrm{Ha}$ have destroyed from forest becomes farm of community cash crop (Subaktini, 2006).

The understanding of the biodiversity of national parks have significant gaps. This lack of information inhibits our ability to understand the magnitude of the loss of species/vegetative diversity and formulate sustainable alternative to resource depletion. The loss or depletion of biodiversity, especially of commercial timber producers while the ability of understanding of these types is still lacking this leads 
to many failures in the replanting effort. On the other hand there are many other species of the desired current value of the timber, requires further research for their genetic diversity and their importance in terms of local use by people who live near the park. There is a need, in future studies, to assess the variability for future sylviculture treatment and breeding. This is especially necessary if these plants assume positions of value in the future, or are overexploited and become rare (Oteng, 1994).

Sustainable forest management is an important issue in Indonesia. Sound forest management cannot possibly be applied without an understanding of the basic ecology of the forest. One prerequisite for sustainable forest management is reliable information on stand dynamic and its characteristics since it is essential to know how the forest will grow and respond to natural condition or occasional disturbances. However, little information is available regarding the dynamic of species composition, structure, biological/species diversity changes of tropical forest in Indonesia over time (Krisnawati $\mathrm{H}$, at all. 2011).

Biodiversity/species diversity (biological diversity) is the variety and variability among living organisms and the ecological complexes in which they occur (Smitinand, 1994). Stand structure is the distribution of trees per unit area (ha) in different diameter classes (Meyer et al., 1961 in Supriyanto et al., 2001). Supriyanto et al., (2001) stated that a natural forest ecosystem is healthy if the structure of the stand represent by different classes of diameter.

Most studies in Indonesia are based on survey on compositional and structural pattern of certain sites of forest at one occasion. Forest vegetation, however, are dynamic and changes occur continuously at individual and species population level throughout time, eventhough the vegetation as a whole is expected to be stable, several studies on forest dynamic in other tropical regions have been conducted (Krisnawati H, at all. 2011).

This paper studies the relationship between elevation level and species occupancy in the ecosystem, in order to achieve good conservation, management and to save the remaining other forest zone in the park. The result was expeted to inform the Meru Betiri National Park vegetation of each elevation level.

\section{Research Method}

\section{Location}

The study was conducted at Meru Betiri National Park area which is located between $8^{\circ} 20^{\prime} 48^{\prime \prime}-8^{0}$ 33 ' 48" S and $113^{\circ} 38^{\prime} 48^{\prime \prime}-113^{\circ} 58^{\prime} 30^{\prime \prime}$ E (see Figure 1). The area is approximately of $58,000 \mathrm{ha}$, of which $\pm 37,585$ ha include in District of Jember and $\pm 20,415$ ha in District of Banyuwangi. Meru Betiri rainfall devides into two parts, the annual average of rainfall in western part of Meru Betiri is $1880.5 \mathrm{~mm}$, and the eastern part is $2094.6 \mathrm{~mm}$. Three soil types dominated in Meru Betiri forest area (Entisol occupied of $47,271.57$ ha; $86.2 \%$ ), Inseptisol $(6,264.304$ ha; $11.4 \%)$ and Spodosol (1,292.954 ha; $2.54 \%)$ (Paimin et al., 2003).

\section{Equipments}

Altimeter, geographic position system, phi-band, compass.

\section{Data Collecting and Analysis}

The survey was collaborated with the Meru Betiri National Park and Watershed Forest Research Institute Surakarta, by using 5 transect lines (20 m wide) as plots across the contour from $0 \mathrm{~m}$ - more than $1,100 \mathrm{~m}$ above sea level (asl). The plots were chosen purposively at the areas where the elevation of $0 \mathrm{~m}$ - more than $1,100 \mathrm{~m}$ asl occurred. The species diversity was studied by grouping into different interval elevation of $100 \mathrm{~m}$ asl.

The sub-plots size varies from $20 \mathrm{~m} \times 20 \mathrm{~m}$ for trees, $10 \mathrm{~m} \mathrm{x} 10 \mathrm{~m}$ for poles, $5 \mathrm{~m} \mathrm{x} 5 \mathrm{~m}$ for saplings, $2 \mathrm{~m} \mathrm{x}$ $2 \mathrm{~m}$ for seedling and undergrowth. Figure 2. Shows the distribution of subplot in each plot. (Soerianegara, I dan Andry, I. 1997).

All plants in each square plot were counted and identified to the species level. Diameter at breast height (DBH) and height were measured and recorded. These data were used for computation of vegetation parameters including density (H'), frequency, basal area and Important Value Index (IVI), and Shannon Wiener Index for diversity. The IVI is a composite index based on measures of relative frequency, relative density, and relative dominance (Mueller- Dombois and Ellenberg, 1974 in Kiratiprayoon et al., 1994). The Shannon-Wiener index relates to the proportional weight of the number of individu per species to the total sample belonging to all species. If $\mathrm{H}$ ' value > 3.00 , species diversity is abundance/high, if the value 1.00 d" 'H' d" 3.00, species diversity is medium, ff H' value $<1.00$, species diversity is rare/low. 


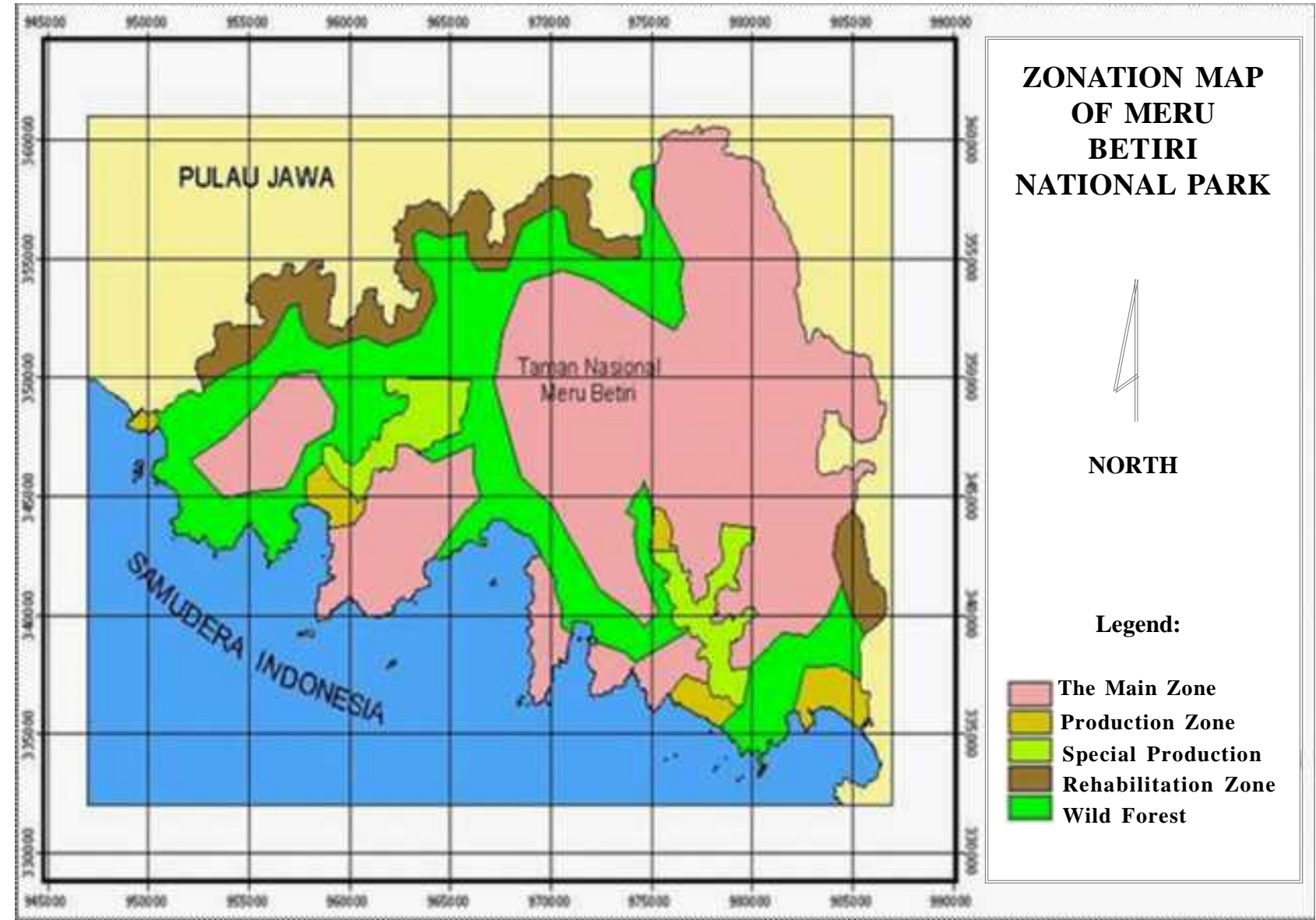

Figure 1. The Study Area

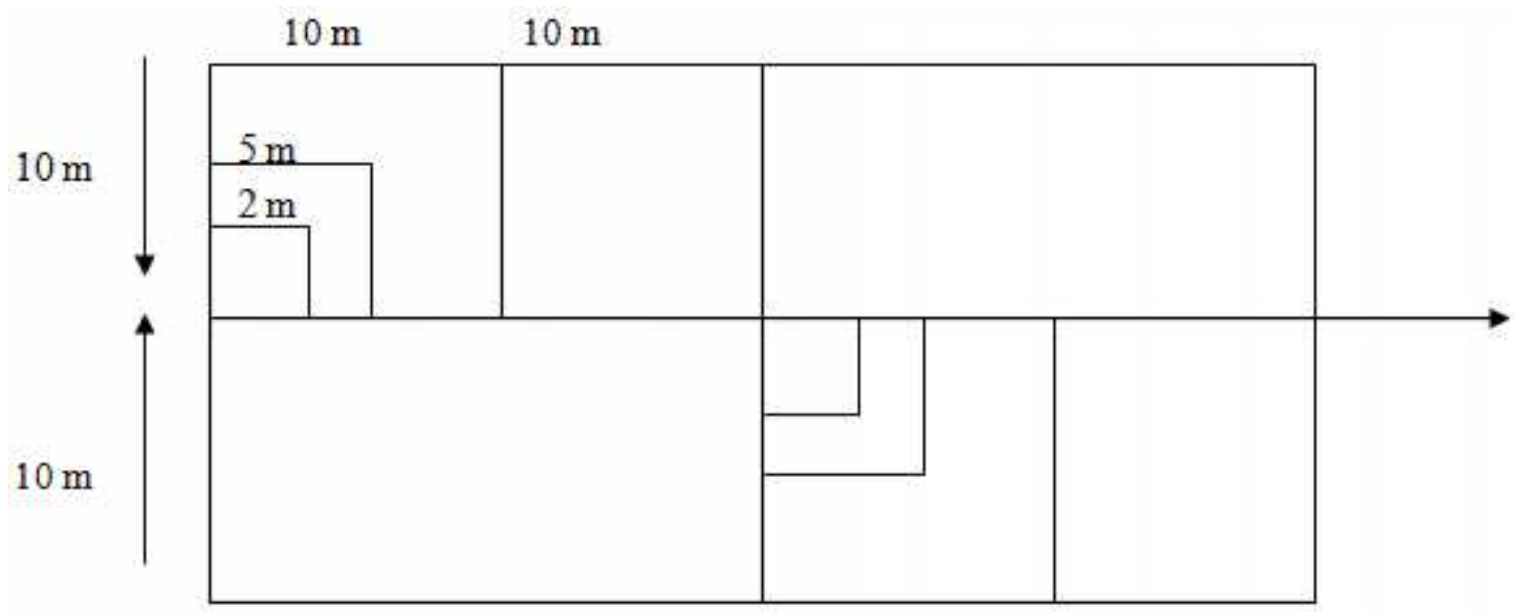

Figure 2. The Distribution of Sub-plots in Each Plot 


\section{Results and Discussion}

\section{Species Diversity}

Species diversity generally describes the composition condition which reflect although sum of species (richness) in one of biological community and also abundance which are distributed among the different species. The observation of diversity can clearly help us to put and start knowing the present situation and future about the distribution. Species diversity of tree, pole, sapling and seeding/undergrowth groups were shown in Figure 3.
In general, in all almost elevation, species diversity value index is on medium value $(1,00 \mathrm{~d}$ " $\mathrm{H}$ ' d" 3,00$)$, only for sapling and trees on more than $1,000 \mathrm{~m}$ asl, the species diversity value index is on rare/low value $\left(H^{\prime}<1\right)$. Based on Samingan (1997) as cited in Kuswanda and Mukhtar. 2009), the habitat condition on elevation under $1,000 \mathrm{~m}$ asl in generally is unconstrained habitat. Still from Figure 2, it is interesting to note that all groups (seedling/undergrowth, sapling, pole and tree) have the same trend line of species diversity, the trend line show there is tend of influence between elevation and species diversity or species existing.
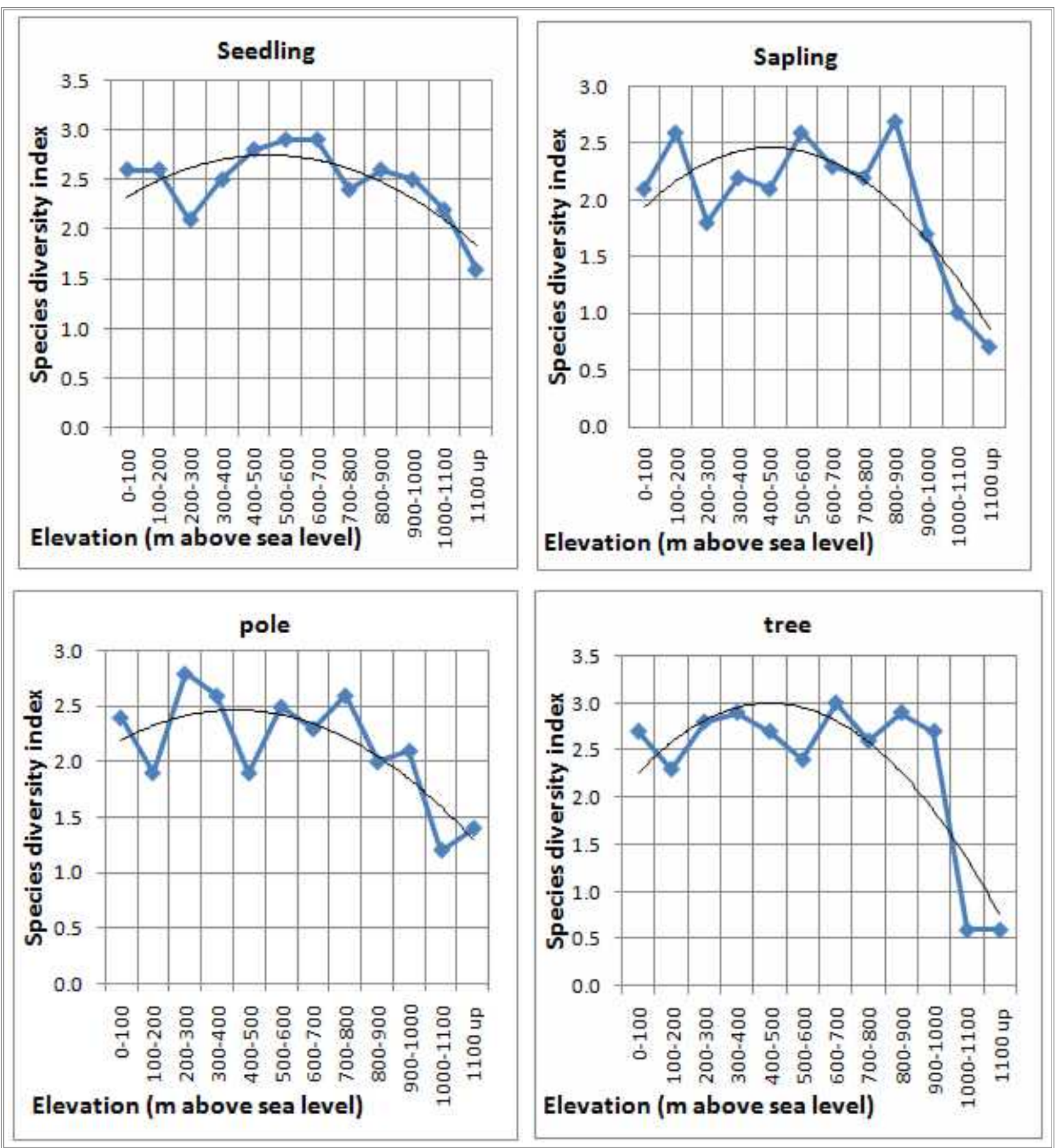

Figure 3. Species diversity index (H') of seedling/undergrowth, sapling, pole, and trees in each elevation 


\section{Stand Structure}

The study of vegetation/species structure is the same as the species diversity study. The stand structure was classified into tree, pole, sapling and seeding/ undergrowth (Table 1). Based on Richard (1964) stand structure is the separation of individual plant in crown layer, and it is meant the separation of trees or plants per hectare within their class diameter (plant/ tree classification). Based on Supriyanto et al. (2001) forest ecosystem health was, if the stand structure represent the class diameter or the plant classification (tree, pole, sapling, seedling and under growth) in the same area.

Not all composition and structure group exist in each elevation level, it means the elevation levels with their own environment influence to the composition and structure group. From the Table 1 showed that the elevation $500 \mathrm{~m}-600 \mathrm{~m}$ asl untill $800 \mathrm{~m}-900 \mathrm{~m}$ asl is the most optimal elevation for the vegetation growth, this is showed by the biggest number of species and number of groups in vegetation structure.

\section{Species Composition}

The analysis of (IVI) was done for knowing the species composition on some level of plants growth, and IVI is a composite index based on measuring of relative frequency, relative density, and relative dominance (Kuswanda and Mukhtar, 2009). This value show the domination level of plants spesies in a land site.

The result of the vegetation/plant class on each elevation with their importance value index, showed at Table 2.

The result from Table 1, Showed there are difference between the elevation $<1000 \mathrm{~m}$ above sea level and $>1000 \mathrm{~m}$ above sea level, especially on the species number and dominant species. More than 30 species occur on $<1000 \mathrm{~m}$ above sea level, and only 11,13 specieses occur on $>1000 \mathrm{~m}$ above sea level. The dominant species (level of plant growth) that is showed by the highest IVI value are : 74\% (tree), $83 \%$ (pole), $79 \%$ (sapling) and $71 \%$ (seedling/under growth) on $<1000 \mathrm{~m}$ above sea level. And on $>1000$ $\mathrm{m}$ above sea level are : 164\% (tree), 111\% (pole), $120 \%$ (sapling) and 68\% (Seedling/under growth).

Table 1. Numbers of species and vegetation classes in each elevation

\begin{tabular}{|c|c|c|c|c|c|c|}
\hline \multirow[t]{2}{*}{ No } & \multirow{2}{*}{$\begin{array}{c}\text { Elevation (M) } \\
\text { (Above sea level) }\end{array}$} & \multicolumn{4}{|c|}{ Vegetation Classes (Number of Species) } & \multirow{2}{*}{$\begin{array}{l}\text { Number of } \\
\text { Species }\end{array}$} \\
\hline & & $\mathrm{A}$ & $\mathrm{B}$ & $\mathrm{C}$ & $\mathrm{D}$ & \\
\hline 1 & $0-100$ & 20 & 11 & 12 & 19 & 44 \\
\hline 2 & $100-200$ & 18 & 13 & 7 & 11 & 39 \\
\hline 3 & $200-300$ & 13 & 8 & 11 & 17 & 33 \\
\hline 4 & $300-400$ & 16 & 10 & 14 & 17 & 41 \\
\hline 5 & $400-500$ & 19 & 15 & 12 & 13 & 43 \\
\hline 6 & $500-600$ & 20 & 9 & 7 & 16 & 44 \\
\hline 7 & $600-700$ & 22 & 11 & 9 & 24 & 48 \\
\hline 8 & $700-800$ & 13 & 9 & 15 & 14 & 46 \\
\hline 9 & $800-900$ & 21 & 16 & 8 & 19 & 51 \\
\hline 10 & $900-1000$ & 16 & 6 & 9 & 17 & 33 \\
\hline 11 & $1000-1100$ & 6 & 3 & 3 & 2 & 11 \\
\hline 12 & $>1100$ & 5 & 2 & 4 & 2 & 13 \\
\hline
\end{tabular}


Table 2. Three highest Importance Value index Species of Tree, Pole, Sapling, Seedling/Undergrowth in each elevation

\begin{tabular}{|c|c|c|c|}
\hline $\begin{array}{c}\text { Elevation } \\
\text { ( m asl) }\end{array}$ & Vegetation C lass & Species & IVI \\
\hline \multirow[t]{12}{*}{$0-100$} & \multirow[t]{3}{*}{ Tree } & Pangium edule & 60.96 \\
\hline & & Lagerstroemia speciosa & 46.21 \\
\hline & & Bischofia javanica & 29.25 \\
\hline & \multirow[t]{3}{*}{ Pole } & Lansium sp. & 57.15 \\
\hline & & Syzygium sp. & 34.12 \\
\hline & & Bischofia javanica & 21.38 \\
\hline & \multirow[t]{3}{*}{ S apling } & Citrus sp. & 68.31 \\
\hline & & Dyospiros hasseltii & 3.67 \\
\hline & & Lansium sp. & $2 ., 38$ \\
\hline & \multirow[t]{3}{*}{ Seedling/Undergrowth } & Citrus sp. & 49.38 \\
\hline & & Ficus sp. & 29.96 \\
\hline & & Calamus sp. & 24.46 \\
\hline \multirow[t]{12}{*}{$100-200$} & \multirow[t]{3}{*}{ Tree } & Garudamar (Unidentified) & 44.18 \\
\hline & & Pangium edule & 35.43 \\
\hline & & Arenga pinnata & 33.87 \\
\hline & \multirow[t]{3}{*}{ Pole } & Pangium edule & 62. 95 \\
\hline & & Mallotus moluccanus & 53.76 \\
\hline & & Barringtonia gigantostachya & 44.26 \\
\hline & \multirow[t]{3}{*}{ S apling } & Calamus sp. & 25.36 \\
\hline & & Alphanamixis grandifloris & 20.87 \\
\hline & & Barringtonia gigantostachya & 15.29 \\
\hline & \multirow[t]{3}{*}{ Seedling/Undergrowth } & Ficus sp. & 44.79 \\
\hline & & Pterospermum javanicum & 21.19 \\
\hline & & Phrynium pubinerve & 19.28 \\
\hline \multirow[t]{12}{*}{ 200-300 } & \multirow[t]{3}{*}{ Tree } & Artocarpus elasticus & 31.37 \\
\hline & & Balikangin (Unidentified) & 30.34 \\
\hline & & Talesan (Unidentified) & 21.85 \\
\hline & \multirow[t]{3}{*}{ Pole } & Ficus benjamina & 49.40 \\
\hline & & Sandoricum koetjapi & 47.19 \\
\hline & & Artocarpus elasticus & 41.23 \\
\hline & \multirow[t]{3}{*}{ S apling } & Citrus sp. & 78.97 \\
\hline & & Aglaia heptandra & 31.22 \\
\hline & & Xantophyllum vitellinum & 26.69 \\
\hline & \multirow[t]{3}{*}{ Seedling/Undergrowth } & Citrus sp. & 71.44 \\
\hline & & Aglaia heptandra & 49.31 \\
\hline & & Pterospermum javanicum & 9.26 \\
\hline \multirow[t]{12}{*}{$300-400$} & \multirow[t]{3}{*}{ Tree } & Ficus benjamina & 74.44 \\
\hline & & Dracontomelon dao & 47.41 \\
\hline & & Pterospermum javanicum & 34.96 \\
\hline & \multirow[t]{3}{*}{ Pole } & Menda rahan (Unidentified) & 46.78 \\
\hline & & Talesan (Unidentified) & 33.32 \\
\hline & & Artocarpus sp. & 20.12 \\
\hline & \multirow[t]{3}{*}{ S apling } & Leea indica & 38.89 \\
\hline & & Donax canniformis & 31.28 \\
\hline & & Aglaia odoratissima & 26.37 \\
\hline & \multirow[t]{3}{*}{ Seedling/Undergrowth } & Donax canniformis & 54.88 \\
\hline & & Calamus sp. & 23.31 \\
\hline & & Ischaemum sp. & 19.17 \\
\hline
\end{tabular}


Table 2. (Continued)

\begin{tabular}{|c|c|c|c|}
\hline $\begin{array}{c}\text { Elevation } \\
(\mathrm{m} \text { asl })\end{array}$ & Vegetation C lass & Species & IVI \\
\hline \multirow[t]{12}{*}{$400-500$} & \multirow[t]{3}{*}{ Tree } & Reces ( Unidentified ) & 35.13 \\
\hline & & Pometia tomentosa & 32.79 \\
\hline & & Antiaris toxicaria & 29.41 \\
\hline & \multirow[t]{3}{*}{ Pole } & Lansium domesticum & 83.45 \\
\hline & & Aglaia heptandra & 53.98 \\
\hline & & Platca latifolia & 34.87 \\
\hline & \multirow[t]{3}{*}{ S apling } & Diospiros hasseltii & 45.44 \\
\hline & & Citrus sp. & 38.39 \\
\hline & & Tales an ( Unidentified ) & 21.88 \\
\hline & \multirow[t]{3}{*}{ Seedling/Undergrowth } & Rakes ( Unidentified ) & 37.43 \\
\hline & & Citrus sp. & 19.98 \\
\hline & & Calamus sp. & 18.34 \\
\hline \multirow[t]{12}{*}{$500-600$} & \multirow[t]{3}{*}{ Tree } & Pometia tomentosa & 52.43 \\
\hline & & Aphanamixis grandifolia & 44.88 \\
\hline & & Antidesma montanum & 34.41 \\
\hline & \multirow[t]{3}{*}{ Pole } & Antidesma montanum & 51.41 \\
\hline & & Tales an ( Unidentified ) & 34.44 \\
\hline & & Styrocarpus burahol & 32.85 \\
\hline & \multirow[t]{3}{*}{ S apling } & Tales an ( Unidentified ) & 33.46 \\
\hline & & Aphanamixis grandifloris & 22.19 \\
\hline & & Chydenanthus exelsa & 20.85 \\
\hline & \multirow[t]{3}{*}{ Seedling/Undergrowth } & Aglaia latifolia & 24.46 \\
\hline & & Phrynium pubinerve & 18.27 \\
\hline & & Piji (Unidentified) & 15.31 \\
\hline \multirow[t]{12}{*}{$600-700$} & \multirow[t]{3}{*}{ Tree } & Litsea diversifolia & 40.89 \\
\hline & & Barringtonia speciosa & 23.33 \\
\hline & & Dracontomelon dao & 17.97 \\
\hline & \multirow[t]{3}{*}{ Pole } & Menda rahan (Unidentified) & 45.34 \\
\hline & & Peleh (Unidentified) & 41.69 \\
\hline & & Morinda citrifolia & 36.31 \\
\hline & \multirow[t]{3}{*}{ S apling } & Aglaia ganggo & 34.37 \\
\hline & & Calamus sp. & 34.37 \\
\hline & & Mallotus moluccanus & 20.41 \\
\hline & \multirow[t]{3}{*}{ Seedling/Undergrowth } & Calamus sp. & 38.89 \\
\hline & & Bambusa sp. & 24.96 \\
\hline & & Areca cathecu & 15.12 \\
\hline \multirow[t]{12}{*}{$700-800$} & \multirow[t]{3}{*}{ Tree } & Teleh (Unidentified) & 44.42 \\
\hline & & Antidesma montanum & 34.23 \\
\hline & & Tuawatu (Unidentified) & 32.31 \\
\hline & \multirow[t]{3}{*}{ Pole } & Getihan (Unidentified) & 34.96 \\
\hline & & Garcinia balica & 31.31 \\
\hline & & Tales an ( Unidentified ) & 27.76 \\
\hline & \multirow[t]{3}{*}{ S apling } & Leea indica & 28.96 \\
\hline & & Chydenanthus exelsa & 19.86 \\
\hline & & Zyzyphus mauritiana & 18.37 \\
\hline & \multirow[t]{3}{*}{ Seedling/Undergrowth } & Hemerocallis fulva & 50.37 \\
\hline & & Donax canniformis & 30.87 \\
\hline & & Citrus sp. & 14.26 \\
\hline
\end{tabular}


Table 3. (Continued)

\begin{tabular}{|c|c|c|c|}
\hline $\begin{array}{c}\text { Elevation } \\
(\mathrm{m} \text { asl })\end{array}$ & Vegetation Class & Species & IVI \\
\hline \multirow[t]{12}{*}{$800-900$} & \multirow[t]{3}{*}{ Tree } & Mallotus moritzianus & 28.41 \\
\hline & & Antidesma montanum & 27.32 \\
\hline & & Mendarahan (Unidentified) & 25.44 \\
\hline & \multirow[t]{3}{*}{ Pole } & Rete-rete (Unidentified) & 58.79 \\
\hline & & Antiaris toxicaria & 53.42 \\
\hline & & Mischocarpus sundaicus & 35.86 \\
\hline & \multirow[t]{3}{*}{ Sapling } & Litsea monopetala & 20.34 \\
\hline & & Talesan ( Unidentified ) & 19.41 \\
\hline & & Aglaia odoratissima & 17.23 \\
\hline & \multirow[t]{3}{*}{ Seedling/Undergrowth } & Calamus sp. & 47.35 \\
\hline & & Talesan ( Unidentified ) & 15.78 \\
\hline & & Agathis alba & 12.41 \\
\hline \multirow[t]{12}{*}{$900-1000$} & \multirow[t]{3}{*}{ Tree } & Aphanamixis grandifolia & 58.31 \\
\hline & & Laportea sinuata & 33.76 \\
\hline & & Pometia samentosa & 22.35 \\
\hline & \multirow[t]{3}{*}{ Pole } & Laportea sinuata & 55.78 \\
\hline & & Aphanamixis polystachys & 49.34 \\
\hline & & Talesan ( Unidentified ) & 32.41 \\
\hline & \multirow[t]{3}{*}{ Sapling } & Aphanamixis grandifloris & 66.27 \\
\hline & & Syzygium sp. & 27.33 \\
\hline & & Ipomea pestigridis & 26.67 \\
\hline & \multirow[t]{3}{*}{ Seedling/Undergrowth } & Areca cathecu & 34.23 \\
\hline & & Pakisan ( Unidentified ) & 30.86 \\
\hline & & Amomum megalochelios & 23.21 \\
\hline \multirow[t]{11}{*}{ 1000-1100 } & \multirow[t]{2}{*}{ Tree } & Aphanamixis grandifolia & 155.42 \\
\hline & & Garcinia balica & 144.58 \\
\hline & \multirow[t]{3}{*}{ Pole } & Garcinia balica & 111.24 \\
\hline & & Aglaia heptandra & 101.36 \\
\hline & & $\begin{array}{l}\text { Tabernaemontana } \\
\text { sphaerocarpa }\end{array}$ & 87.40 \\
\hline & \multirow[t]{3}{*}{ Sapling } & Calamus sp. & 120.11 \\
\hline & & Kecombrang (Unidentified) & 39.64 \\
\hline & & Sepat (Unidentified) & 40.25 \\
\hline & \multirow[t]{3}{*}{ Seedling/Undergrowth } & Garcinia balica & 48.25 \\
\hline & & Leea indica & 30.21 \\
\hline & & Aglaia heptandra & 19.42 \\
\hline \multirow[t]{10}{*}{$>1100$} & \multirow[t]{2}{*}{ Tree } & Keningar (Unidentified) & 163.72 \\
\hline & & Sepat (Unidentified) & 136.28 \\
\hline & \multirow[t]{3}{*}{ Pole } & Cyperus rotundus & 78.23 \\
\hline & & Keningar (Unidentified) & 74.79 \\
\hline & & Vitex pubescens & 75.34 \\
\hline & \multirow[t]{2}{*}{ Sapling } & Michelia velutina & 116.66 \\
\hline & & Sint ok (Unidentified) & 83.34 \\
\hline & \multirow[t]{3}{*}{ Seedling/Undergrowth } & Dendrobium sp. & 40.38 \\
\hline & & Aphanamixis polystachys & 36.86 \\
\hline & & Pandanus sp. & 12.79 \\
\hline
\end{tabular}




\section{Discussion}

From the result that we have mentioned above, this prove that higher elevation on tropical rain forest influence the species separation (Ewusie 1990). Tivy (1993) in Setyawati, 1998) stated that the climate changes caused by elevation difference should make biotic zone that will show different species/vegetation formation in each elevation.

Based on Sumarwoto (1983 in Irwan, 1997) each species has difference tolerance to the environment, same opinion by Boughey (1973 in Wirakesumah, 2003) every ecologic factor where the organisms give their response there are maximum and minimum influence, this fenomena calls as tolerance boundary. The consept of tolerance boundary usually was applied to study the separation schema. Any rationalized strategy for species diversity conservation must be based on those information. To set aside conservation areas that will protect the fullest range of species requires more complete knowledge of the distribution and abundance of organisms . (Lubchenco et al 1991 in Gajaseni and Boonpragob, 1994).

For the enrichment planting purpose by considering the right species with their elevation is the most importance in order to success the purpose. Species with the biggest importance value index must be chosen than the other ones with smaller importance value index, can be consider as vegetation materials to the purpose above. Petocz (1987 in Lekito and Max, 2003) said that more higher place from above sea level, the floral diversity is lower, but higher in species vegetation endemic value.

\section{Conclusion}

(1) The highest and the lowest of species diversity $\left(\mathrm{H}^{\prime}\right)$ : at seedling/undergrowth group respectively are : the highes is 2.90 on $600-700 \mathrm{~m}$ asl, and the lowest is 1.60 on up to $1100 \mathrm{~m}$ asl; at sapling group the highest is 2.70 on $800-900 \mathrm{~m}$ asl the lowest is 0.70 on up to $1100 \mathrm{~m}$ asl; at pole group the highest is $2.80 \mathrm{on}$ $200-300 \mathrm{~m}$ asl and the lowest is 1.20 on $1000-1100$ $\mathrm{m}$ asl , and at tree group the highest is 3,00 on 600$700 \mathrm{~m}$ asl, the lowest is 0.70 on up to $1100 \mathrm{~m}$ asl, (2) Higher of the elevation on Meru Betiri National Park, the species diversity index were tend to decrease but more higher of the endemic value of the species such as Morinda citrifolia (tree), Vitex pubescens (pole), Michelia velutina (sapling) and Dendrobium $\mathrm{sp}$ (seedling/undergrowth), (3) The structure group and the composition of species is influenced by elevation levels with their own environment

\section{References}

Departemen Kehutanan. 1999. Undang-Undang Kehutanan No. 411999.

Ewusie, J.Y. 1990. Pengantar Ekologi Tropika: Membicarakan Alam Ekologi Tropika Afrika, Asia, Pasifik dan Dunia Baru. Terjemahan Usman Tabuwijaya. Institut Teknologi Bandung, Bandung.

Gajaseni, J. and K. Boonpragob. 1994. Method for Measurement of Species Diversity. Proceeding of a IUFRO Symposium. Measuring and Monitoring Biodiversity in Tropical and Temperate Forest: 303-307.

Irwan, N.D. 1997. Prinsip-prinsip Ekologi dan Organisasi Ekosistem Komunitas dan Lingkungan. Bumi Aksara.

Kiratiprayoon, S., L. Jesada, D. Pralong, T. Metinee. 1994. Species Diversity of Second Growth at Ngao Demonstration Forest, Lampang Province. Proceeding of a IUFRO Symposium. Measuring and Monitoring Biodiversity in Tropical and Temperate Forest : 237-245.

Krisnawati.H, Djoko.W, Rinaldi. I. 2011. Changes in The Species Composition, Stand Structure And Aboveground Biomass of A Lowland Dipterocarp Forest in Samboja, East Kalimantan.

Kuswanda, W and A.S. Mukhtar. 2009 Kondisi Vegetasi dan Strategi Perlindungan Zona Inti di Taman Nasional Batang Gadis, Sumatera Utara (Vegetation Condition and Strategis for Protecting Sanctuary Zone At The Batang Gadis National Park, North Sumatera) Info Hutan Vol. VI (1) Tahun 2009, Pusat Penelitian dan Pengembangan Hutan Dan Konservasi Alam, Bogor: 59-74

Lekito, K. dan J.T. Max. 2003 Pengaruh Elevasi Terhadap Keragaman Jenis dan Rata-rata Tinggi Pohon pada Koridor C.A. Pegunungan Tamrau Utara dab S.M. Jamursba- Medi, Sorong Papua. Buletin Penelitian Hutan No. 640 Tahun 2003 Bogor: 20-25 
Oteng, A.A. 1994. Biodiversity Assessment of Forest Tree Species in Bia National Park Ghana. Proceeding of a IUFRO Symposium. Measuring and Monitoring Biodiversity in Tropical and Temperate Forest: 247256.

Paimin, H. Beni, D.R. Heru, Purwanto, B.S. Agung, W. Agus. 2003. Laporan Kajian Kriteria dan Indikator Penetapan Zonasi Taman Nasional Meru Betiri- Jember. Balai Penelitian Dan Pengembangan Teknologi Daerah Aliran Sungai.Solo (Tidak diterbitkan).

Peraturan Pemerintah No. 68 Tahun 1998. Tentang Kawasan Suaka Alam dan Kawasan Pelestarian.

Setyawati, T. 1998. Studi Fisiognomi Vegetasi Hutan di Kawasan Taman Nasional Gunung Gede Pangrango Jawa Barat, Buletin Penelitian Hutan No. 612 Tahun1998 Bogor : 27-37.

Smitinand, T. 1994. Overview of the Status of Biodiversity in Tropical and Temperate Forest. Proceeding of a IUFRO Symposium. Measuring and Monitoring Biodiversity in Tropical and Temperate Forest : 1- 4.

Subaktini,D. 2006. Analisis Sosial Ekonomi Masyarakat Di Zona Rehabilitasi Taman Nasional Meru Betiri, Jawa Timur. Forum Geografi, Jurnal Geografi Universitas Muhammadiyah Surakarta.

Supriyanto, U.S. Irawan, E.I. Putra. 2001. Stand Structure (Status, Change, Trends) in Forest Health monitoring. Forest Health Monitoring to Monitor the Sustainability of Indonesian Tropical Rain Forest.

Wirakesumah, S. 2003. Dasar-dasar Ekologi Bagi Populasi dan Komunitas. UI- Press Jakarta. 